\title{
EVALUATION THE IMPLEMENTATION OF TRIAS OF SCHOOL HEALTH CENTER PROGRAM AT GIWANGAN ELEMENTARY SCHOOL, YOGYAKARTA
}

\author{
Lina Eta Safitri1,2) \\ 1) Faculty of Public Health, Universitas Ahmad Dahlan, Indonesia \\ 2)Masters Program in Public Health, Universitas Sebelas Maret
}

\begin{abstract}
Background: After families, school plays an important role in taking account of children's health at elementary school. This is because students spend a lot of time at schools and often encountered various health problems. Studies have shown that School Health Based Centre are particularly suited to meet the children needs for proper health services. This study aimed to evaluate the implementation of trias of school health center program (UKS) at Giwangan elementary school, Yogyakarta.

Subjects and Method: This was a qualitative study with case study approach. The study was conducted at Giwangan elementary school, Yogyakarta, Indonesia, in May 2018. The key informants were supervisor and head of UKS. The informants were selected by purposive sampling. The data were collected by in-depth interview, observation, and study document.

Results: Input evaluation showed that facilities and infrastructure in the school health center were not optimally available. Evaluation process found that there were some obstacles faced by school health center in providing health education in students. Output evaluation showed that there was lack of personnel to implement school health center service. There has never been a little doctor training for students.

Conclusion: There is a need to improve facilities and number of personnel in school health center.
\end{abstract}

Keywords: school health center program, evaluation

Correspondence:

Lina Eta Safitri. Masters Program in Public Health, Universitas Sebelas Maret. Jl. Ir. Sutami 36A, Surakarta 57126, Central Java. Email:linaetasafitri_96@student.uns.ac.id

The $7^{\text {th }}$ International Conference on Public Health

Solo, Indonesia, November 18-19, 2020 367

https://doi.org/10.26911/the7thicph.04.52 